\title{
Independent inventors and inbound open innovation: using a resource-based approach to create a tool for screening inventor approaches in order to facilitate technology in-licensing
}

\author{
Gavin Smeilus* \\ University of Wolverhampton, Wulfruna Street, Wolverhampton, WV1 1LY, United \\ Kingdom. \\ E-mail: G.E.Smeilus@wlv.ac.uk

\section{Robert J. Harris} \\ University of Wolverhampton, Wulfruna Street, Wolverhampton, WV1 1LY, United \\ Kingdom. \\ E-mail: R.J.Harris@wlv.ac.uk

\section{Andrew Pollard} \\ University of Wolverhampton, Wulfruna Street, Wolverhampton, WV1 1LY, United \\ Kingdom. \\ E-mail: A.Pollard@wlv.ac.uk \\ * Corresponding author
}

\begin{abstract}
Open innovation literature identifies independent inventors as a source of novel external knowledge. This knowledge may be licensed into an organisation in order to supplement internal R\&D activity, typically as part of an inbound open innovation strategy. In opening an organisation up to approaches from individuals the capacity of the core team to identify promising licensing opportunities is diminished by the sheer volume and variable quality of approaches received.
\end{abstract}

Based on a survey of 202 UK independent inventors this paper utilises a resource-based approach to identifying the key resources possessed by successful independent inventors. Using this data, we devise a preliminary screening tool to facilitate technology in-licensing from independent inventors.

Keywords: Independent inventors; licensing; open innovation; new product development, resourcebased perspective

\section{Introduction}

Academic literature relating to Open Innovation, which is defined as: “... the use of purposive inflows and outflows of knowledge to accelerate internal innovation, and expand the markets for external use of innovation, respectively" (Chesbrough, Vanhaverbeke \& West, 2006, p.1), identifies independent inventors as an external source of knowledge that businesses may wish to leverage as part of an inbound open innovation strategy (Chesbrough et al., 2006; Bughin et al., 2008; Lazzarotti et al., 2009). While other cited external knowledge sources: competitors, users, suppliers, universities and research institutes have received considerable levels of academic attention concerning their ability to contribute towards an organisations new product development processes (Kaufman et al., 2000; 
Sobrero and Roberts, 2002; Olson and Bakke, 2001; Lilien et al., 2002; Bonner and Walker, 2004; Dahan and Hauser, 2002; von Hippel and Katz, 2002; Gassmann et al., 2006; Dittrich et al., 2007; Perkmann and Walsh, 2007) we have found little evidence to suggest that the integration of independent inventors within the open innovation business model has received consideration.

The lack of empirical research into independent inventors (MacDonald, 1986; Weick and Eakin, 2005; Mayer, 2005) does little to encourage or facilitate the use of independent inventors as an external source of knowledge for businesses operating inbound open innovation models. Indeed, the neglect of independent inventors within academic literature relating to open innovation is mirrored in an industrial context, where external knowledge sources utilised by businesses typically exclude independent inventors. To illustrate this point, the survey of 144 companies by Enkel and Gassmann (2008) identifies that the most frequently used external knowledge sources for businesses are: clients (78\%), suppliers (61\%), competitors (49\%), and public and commercial research institutions (21\%).

While a conclusion may be drawn that independent inventors are simply not an important source of innovation and this is the reason why academics and businesses operating open innovation choose to marginalise this group, independent inventors do seem to offer something valuable and merit consideration. Schumpeter (1939) suggests that independent inventors play a key role in the process of societal economic renewal, while Astebro and Michela (2005) identify independent inventors as a source of radically different and commercially successful innovations. Indeed, it is argued that the innovative outputs of inventors offer an important contrast to the incremental innovations typically developed by company R\&D departments (Schrage, 2003; Prusa and Schmitz, 1991).

For more organisations to seriously consider integrating independent into inbound open innovation more information relating to these individuals must be available and we must build upon the experiences of the few organisations that have collaborated with independent inventors in order to build processes that facilitate this collaboration.

While we acknowledge that there is no "typical" organisational structure adopted by businesses operating inbound open innovation (Martinez and Jarillo, 1989), a formal approach to organising for this type of activity may include the development of a "Core Team" whose role it is to “...coordinate a number of activities aimed at leveraging the external sources of innovation” (Mortara and Minshall, 2011 p. 591). A significant problem for the few organisations that have attempted to integrate independent inventors into their new product development processes, the Caparo Group for example, is the sheer volume (Smeilus et al., 2011a) and variable quality (Astebro, 2003; Dahlin et al., 2004) of 
approaches received, which makes identification of promising licensing opportunities by the core team difficult, labour intensive and costly to administer.

The purpose of this paper is two-fold, firstly we seek to provide organisations operating inbound open innovation models with data on independent inventors and their activity, so that they may be better informed of the characteristics of this source of external knowledge. Secondly, we propose a preliminary screening tool that facilitates the identification of independent inventors that are most likely to offer promising technology in-licensing opportunities. We attempt to accomplish these aims by profiling UK independent inventors and identifying the resource bundle inventors need to possess in order to achieve a licensing agreement with a third party business. We then translate the resources synonymous with licensing success into a question-set that allows the screening of independent inventor approaches.

The decision to focus on technology in-licensing as the mechanism whereby businesses leverage independent inventor knowledge is based on two factors. Firstly, data provided by Weick and Eakin (2005) identifies that licensing the intellectual property rights behind an innovation is the preferred commercialisation option for independent inventors. Secondly, technology in-licensing is an acknowledged and widely used mechanism within open innovation (Chesbrough and Crowther, 2006; Spithoven et al., 2011; Bianchi et al., 2011).

The following research objectives are proposed as a method of achieving the aims of this inquiry:

\section{Research Objectives}

1. To identify the key resource bundle possessed by successful independent inventors

2. To suggest a preliminary screening tool that enables businesses involved in inbound open innovation to more readily identify promising technology in-licensing opportunities from independent inventors.

With regard measuring "success", previous studies into either independent inventor commercialisation attempts, or technology licensing at an organisational-level, use a range of success indicators, including: launching the invention on the market (Astebro, 2003); licenses agreed and royalty income derived (Owen-Smith and Powell, 2001; Jensen et al., 2003) and number of license agreements signed (Thursby and Kemp, 2002). For the purpose of this paper the term "Successful inventor" denotes that the independent inventor has achieved a signed license agreement.

In terms of the structure for this paper we first briefly profile independent inventors before suggesting priori resource requirements for inventor success. Following analysis of a UK survey of independent 
inventors, we identify the resource bundle possessed by successful independent inventors. We conclude by detailing a preliminary screening tool to help an organisations core team identify promising technology in-licensing opportunities from independent inventors.

\section{Literature Review}

\section{Defining and profiling the independent inventor}

Lettl et al.(2009) suggest that independent inventors are characterised by two factors; firstly their inventive activity is conducted outside the confines of an established business and secondly, the independent inventor has no formal obligation to invent.

Independent inventors tend to be male as opposed to female (Parker et al., 1996; Albaum, 1975) and are likely to be in their late forties to early fifties (Albaum, 1975; Sirilli, 1987; Weick and Eakin, 2005). In terms of formal qualifications independent inventors are more educated than the general populous (Parker et al., 1996) with a high proportion having undertaken graduate or post-graduate training (Albaum, 1975)

Few independent inventors have entrepreneurial aspirations (Parker et al.,1996), they are typically skilled in the identification of problems (Weick and Martin, 2006) and value both “...autonomy and individuality” (Weick and Martin, 2006, p.10) despite the existence of opportunities to collaborate.

Why integrate independent inventors into open innovation?

The rationale behind the integration of independent inventors into open innovation has been articulated in a handful of studies. At the centre of the debate is the notion that independent inventors, by their very definition, have “...the freedom to think 'outside the box"” (Lettl et al., 2009, p.244), which it is argued facilitates the development of radical, as opposed to incremental, innovations. Indeed, independent inventors have long been seen as a source of inventive breakthroughs (Schumpeter 1934; Hughes, 2004; Schrage, 2003; Prusa and Schmitz, 1991). Such inventive breakthroughs can translate into significant financial returns for the parties involved (Astebro, 2003).

\section{Why have independent inventors been marginalised?}

Numerous academics have presented their views as to why businesses are reluctant to open up to approaches by independent inventors. Parker et al. (1996 p.7) suggest that: "The independent inventor has often been portrayed as something of a mad scientist-type individual or an uneducated dreamer in search of the holy-grail. The result of this perception is that the independent inventor no longer is viewed as a serious source of product innovation.” Whalley (1991 p.225) adds to this debate by confirming that businesses are all too willing to believe the negative image of inventors as “...odd, even crazy...” 
Aside from negative stereotypes, the reticence businesses display towards opening up to independent inventors is likely to be a result of a number of factors: firstly, the low probability of capturing a commercially successful innovation from this source. Dahlin et al., (2004) suggest that independent inventors are disproportionately represented in the tails of creative distribution curves; signifying that they develop both unoriginal and highly innovative outputs. This phenomenon is reflected in the financial analysis of independent inventor outputs conducted by Astebro (2003) who points to the fact that whilst a return of $1400 \%$ or more was achieved by 6 of the 75 commercialised innovations studied, $60 \%$ of the 75 innovations yielded a negative return with the median figure standing at $-7 \%$. Indeed the comparatively low commercial success rate of innovations emanating from independent inventors is concerning: Smeilus et al. (2011a) identify a commercial success rate of $0.7 \%$ for innovations offered to an existing open innovation centre, whilst Astebro (2003) suggests an average probability of commercialisation of 0.07 . These figure fare poorly when compared to the probability of achieving commercial success of 0.27 for innovations emanating from large corporations (Mansfield et al.,1977b).

A second factor acting as a barrier to engagement is the negative effects businesses face when administering high volumes of diverse independent inventor approaches. The literature stream on absorptive capacity highlights the difficulties an organisation may have in assimilating external knowledge that falls outside of the organisations comprehension (Zahra and George, 2002). The diversity of independent inventor approaches is therefore problematic because not all approaches will fit within fields of specialism. Similarly, the volume of approaches may also lead to negative repercussions. Kotabe et al. (2007) suggest that high volumes of transferred knowledge can be detrimental to absorptive capacity. This phenomenon is attributed to the following:

- Too much knowledge transfer dilutes the receiving company's ability to assimilate the knowledge effectively

- As increased knowledge transfer occurs, the receiving company's costs increase as they attempt to manage the process and dedicate resource to the assimilation of the knowledge. (Kotabe et al., 2007)

To this end Kotabe et al., (2007) recommend that innovative performance is enhanced by restricting knowledge transfer to a few sources, particularly those that yield high quality knowledge. Set against this context the marginalisation of independent inventors by businesses is perhaps understandable.

While accepting that there are significant barriers to integrating independent inventors into corporate new product development, the rewards of successful integration have the potential to be significant, particularly if some of the noise surrounding the licensing interface can be minimised; in particular the high volume of unviable or unoriginal inventor approaches that are made (Dahlin et al., 2004). 
Applying the Resource-based perspective to the study of independent inventors

Typically applied in the field of strategic management, the resource-based perspective has benefitted from being utilised across a number of other disciplines (Barney, 2001). Its utilisation in the field of innovation management is therefore not unusual.

While the resource-based perspective traditionally focusses upon understanding how firms achieve a sustainable competitive advantage (Barney, 1991), the theory has also been associated with developing strategic advantage (Barney, 2001) and innovative advantage (Lacetera et al., 2004; Rothaermel and Hess, 2007). In the context of this paper we are concerned with analysis of innovative advantage; in particular the independent inventors' capacity to succeed in achieving a licensing deal.

The unit of analysis within the resource-based perspective is typically the firm (Barney, 1991); however Alvarez and Busenitz (2001) contribute to the expansion of the theory by adopting the resource, rather than the firm, as the unit of analysis. This decision is critical to this paper since it paves the way for the theory to be applied when investigating the actions of individuals.

When consideration is given to the conversion of resources into innovative advantage the resourcebased perspective suggests that processes and routines act as the facilitation vehicle (Barney, 1997; Barney and Mackey, 2005).

\section{Independent inventors: Priori resource requirements for licensing success}

If we adopt resource-based theory (Barney, 1991) then the resources associated with independent inventors can be logically classified into two categories: Physical Capital Resources (Williamson, 1975) and Human Capital Resources (Becker, 1964). Previous work (Smeilus et al. 2011b) suggests that the following resources have the potential to impact upon independent inventor success:

Table 1: Resources important to independent inventors achieving success via a licensing agreement

\section{Insert table 1 here}

\section{Physical Capital Resources:}

Independent inventor success appears to be influenced by their capacity to access physical resources. Whalley (1991) suggests that access to inventive space, raw materials and appropriate equipment and machinery is an important resource requirement; particularly when considering mechanical product innovations.

In terms of financial resource the majority of independent inventors are reliant upon their own personal funds to advance their invention (Whalley, 1991). 
Hypothesis 1: Independent inventor success will be a significant and positive function of possessing appropriate physical capital resources.

\section{Human Capital Resources - Qualifications}

Cohen and Levinthal (1990) suggest that the ability to assimilate new knowledge is influenced by a person's current body of knowledge. As such those inventors that are more highly qualified are arguably in a better position to assimilate new knowledge. Transnational Innovation Network theory suggests that innovation occurs as the result of knowledge being transferred or shared around the world, whereby it is either utilised in its original form or reapplied in a new way (Coe and Bunnell, 2003). If innovation occurs as a result of knowledge being transferred and the possession of knowledge is the basis upon which new knowledge is acquired then arguably those inventors that are more highly qualified will be most likely to make important new inventions and achieve licensing success.

Hypothesis 2: Independent inventor success will be a significant and positive function of the level of formal qualifications they hold

Possessing qualifications in the same field in which they are inventing may benefit independent inventors. Lettl et al. (2009) found evidence that focussing inventive efforts in an industry where the independent inventor has some specialist knowledge is beneficial to the prospect of an impactful technology being developed.

Hypothesis 3: Independent inventor success will be a significant and positive function of possessing formal qualifications in the field in which they are inventing

Human Capital Resources - Previous experience of inventing

Weick and Martin (2006) propose that inventors with previous experience of new product commercialisation are more likely to achieve commercial success. When examining organisational level literature the positive effects of previous experience is also noted; Lynn et al., (1999) identify the need for relevant experience and the ability to learn lessons from previous projects as fundamental to success.

Hypothesis 4: Independent inventor success will be a significant and positive function of their previous experience of new product commercialisation

\section{Human Capital Resources - Financial expectations}

Independent inventors must realise businesses are driven primarily by financial return when introducing new products and that this objective may contravene their own aspirations (Whalley, 1991). As such, inventors that share this financial objective maybe more attractive licensors. 
Hypothesis 5: Independent inventor success will be a significant and positive function of a desire for a return on investment from inventive efforts

Human Capital Resources - Characteristics of potential licensees

The selection of potential licensees is a difficult task. Initially, inventors need a basis upon which to refine their search. Mayer (2005) suggests that manufacturing capability and access to appropriate markets in which to offer the invention are important characteristics of potential licensees.

In terms of gaining access to potential licensees businesses are sceptical of independent inventors because of the associated costs of administering enquiries compared to the probability of achieving a suitable financial return (Whalley, 1991; Astebro, 2003).

Hypothesis 6: Independent inventor success will be a significant and positive function of their ability to identify and gain access to potential licensees

Hypothesis 7: Independent inventor success will be a significant and positive function of judgements concerning the characteristic of potential licensees

\section{Routines - Collaboration and networks}

The concept of innovation networks (Coe and Bunnell, 2003) suggests that independent inventors with enhanced network linkages will benefit, both prior to invention conceptualisation and during the new product development process. Initially, the act of invention occurs as a result of knowledge being transferred through networks whereby said knowledge is either utilised in its original form or reapplied in a new innovative way (Coe and Bunnell, 2003). Independent inventors who interact with corporations; those that can strike up social relationships with knowledgeable individuals; and those that utilise knowledge from published sources should be better placed to generate innovative ideas (Coe and Bunnell, 2003).

Whalley (1991) suggests that individual inventors lack the mutual support groups that can be found in other creative disciplines. However, we identify the network of UK Inventor Clubs as a source of social support open to inventors. Interestingly, Lettl et al., (2009) confirms that independent inventors who actively engage with social support networks and communities are more able to access resources that are usually reserved for corporate inventors.

Hypothesis 8: Independent inventor success will be a positive and significant function of inventor club membership.

Hypothesis 9: Independent inventor success will be a positive and significant function of their collaboration with knowledge-laden institutions 
Hypothesis 10: Independent inventor success will be a positive and significant function of collaboration with external professionals

\section{Routines - Assessment processes}

Cooper and Kleinschmidt (2007) recommend that assessments are made of the technical and market potential of innovations throughout the development process. These assessments move from preliminary overviews of potential into increasingly detailed insights. Key components of the assessments include: market research with potential end-users; assessment of technical requirements: possible manufacturing methods, technical viability of proposition, costs associated with production, timescale and resource requirements; analysis of the financial case at different levels of sensitivity.

Hypothesis 11: Independent inventor success will be a positive and significant function of utilising commercial and technical assessments as part of the new product development process

In appraising the hypotheses derived from the literature, it is important to note that while many of the hypotheses identified in this section maybe perceived as unoriginal in the context of licensing success at an organisational-level or when considering independent inventor commercialisation success in general terms, we believe that in the context of studying individual actions relating specifically to the licensing commercialisation mode the hypotheses suggested have yet to be tested.

\section{Methodology}

A quantitative survey of UK independent inventors was conducted between March 2011 and December 2011. The survey was made accessible in both online and paper based formats.

A total of 939 invitations to participate in the survey were issued; 579 email invitations with a link to the online survey and 360 paper-based questionnaires issued by post. 258 questionnaire returns were received; a response rate of $27 \%$. Of the 258 returns 202 were complete and usable responses. Previous studies focusing on independent inventors include: Parker et al. (1996) 141 inventor responses and Huber (1998) 162 inventor responses.

The question-set used within the survey was derived directly from the critical success factors (CSF's) established by Smeilus et al. (2011b). The constructs associated with the CSF's were categorised as physical resources, human resources and routines, identified in Table 1, with the intention that analysis of the data will reveal the resource bundle that allows some inventors to realise a completed license agreement, whilst others falter. 
The survey was restricted to the UK and limited to independent inventors as defined previously in this paper.

\section{Sampling}

Non-probability sampling was utilised for this study and as such we acknowledge that the sample may not be representative of the entire UK independent inventor population. A purposive sampling technique: snowball sampling was employed to enable contact with individuals that comply with the definition of independent inventor employed within this study. The selection of this particular sampling technique was based on the difficulty in identifying independent inventors within the wider population. While organisations that support independent inventors are identifiable few of these maintained a database of contacts that would facilitate the use of alternative sampling methods. In view of this we initially invited independent inventors to participate in the survey via the Caparo Innovation Centre and UK inventor Clubs who maintain contact databases. We asked these initial recipients to forward the contact details of other independent inventors they were aware of to us, so that further survey invitations could be issued. In justifying the use of snowball sampling we refer to the work of Felix-Medina and Monjardin (2010) who advocate the use of this technique when attempting to sample hidden or difficult to access human populations, such as independent inventors.

The dependent variable considered within this study is the level of independent inventor success with regards to licensing. We utilise three categories:

1. Independent inventor has achieved licensing success

2. Independent inventor is attempting to licence their technology, but as yet remains unsuccessful

3. Independent inventor has not engaged with the licensing process to date.

\section{Results}

Analysis of the survey data was undertaken using the SPSS software package. Two statistical techniques were applied: Pearson's Chi Square analysis and one-way ANOVA. Pearson's Chi-Square analysis was undertaken to establish whether there was a relationship between selected categorical variables. This particular statistical test was deemed appropriate because the dependent variable contained three groups:

1. Independent inventor has achieved licensing success

2. Independent inventor is attempting to licence their technology, but as yet remains unsuccessful

3. Independent inventor has not engaged with the licensing process to date. 
One-way ANOVA was used to test the equality of three means simultaneously by utilising variances. This test, rather than a t-test, was applied because of the existence of the three groups, identified previously, within the dependent variable.

\section{Profile of UK independent inventors}

Of the 202 respondents to the survey the following level of independent inventor success with regards to the licensing process was recorded:

Table 2: Level of Independent inventor success with regards to licensing

\section{Insert table 2 here}

Of the independent inventors that have successfully licensed their technology to a third-party business the majority are Male, most likely aged 61-years or older and employed in either full-time or part-time roles.

Table 3: Profile of the three Independent inventor groups

$$
\text { Insert table } 3 \text { here }
$$

\section{Independent inventor resources}

In the following section we present details concerning the resource bundle commanded by the three inventor groups.

\section{Physical capital resources - Capacity to self-finance the development programme}

In terms of physical capital resources we first consider the independent inventors capacity to selffinance the development programme. Successful independent inventors were most likely to be able to fully self-finance their development programme and least likely to be unable to self-finance any aspect, however following Pearson chi-square analysis we did not find any evidence to suggest that the differences in the ability to self-finance the development process across the three inventor groups is significant when considering inventor success $\chi^{2}(4, N=179)=2.63, P=.61$

Table 4: Independent inventor capacity to self-finance their development programme

$$
\text { Insert table } 4 \text { here }
$$

Physical capital resources - Access to inventive space 
In terms of inventive space, the data in table 5 highlights an interesting feature in that whilst successful inventors are less likely than their counterparts to invent at home or in the garage, they are more likely to have access to a dedicated workshop in which to pursue their activity.

Table 5: Physical space inventors have access to in order to pursue their development programme.

\section{Insert table 5 here}

Indeed, chi Square analysis of the data relating to inventive space allows us to confirm a significant relationship between independent inventor success and having access to a dedicated workshop to support development $\chi^{2}(2, N=201)=7.26, P=.03$

\section{Physical capital resources - Access to machinery and equipment resources}

Whilst successful inventors are more likely to agree that they can gain access to the machinery and equipment required to develop prototypes, a one-way ANOVA of the capacity to gain access to machinery/equipment resources yields no significant differences between the groups, $(F(2,193)=$ $1.71, \mathrm{P}=.18)$.

\section{Physical capital resources - Access to raw materials}

Successful independent inventors are more likely to have access to the raw materials required to produce prototypes. To ascertain the significance of this relationship a one-way analysis of variance was performed. Since the homogeneity of variances assumption was violated $(\mathrm{P}=.01)$ we used Welch's adjusted F ratio, which was significant at the alpha level of .05 $(F(2,70.15)=3.25, P=.045$ Post-hoc comparisons of the three groups using the Games-Howell procedure was conducted and revealed differences in the means of those inventors that had successfully licensed their technology and those that were not engaged $(\mathrm{P}=.04)$.

Following analysis of the physical resources inventors possess we accept: Hypothesis 1: Independent inventor success will be a significant and positive function of possessing appropriate physical capital resources. This decision is made on the basis that we find evidence to support a significant and positive link between inventor access to a dedicated workshop and inventor success and the inventor's ability to access raw materials to produce a prototype and inventors success.

\section{Human capital resources - Highest level of qualification}

Table 6: Highest level of qualification held by Independent inventor 
A sizable proportion of independent inventors across all three groups possess a graduate qualification or higher. Indeed, we do not find any evidence to suggest that differences in educational attainment across the three inventor groups is significant when considering inventor success $\chi^{2}(2, N=186)=$ $4.02, P=.13$

We reject Hypothesis 2: Independent inventor success will be a significant and positive function of the level of formal qualifications they hold

$$
\text { Human capital resources - Synergy between qualifications and field of invention }
$$

Table 7: Synergy between qualifications and field of invention

\section{Insert table 7 here}

Whilst the level of qualifications held by independent inventors is not significantly related to inventor success, we get interesting results when we look at the discipline in which they are qualified. Indeed, Pearson's chi-squared analysis identifies a significant and positive relationship between independent inventor success and the possession of formal qualifications in the technical field in which the independent inventor is inventing $\chi^{2}(2, N=195)=7.33, P=.03$

We accept Hypothesis 3: Independent inventor success will be a significant and positive function of possessing formal qualifications in the same field in which they are inventing.

\section{Human capital resources - Previous experience of new product commercialisation}

In terms of previous direct or indirect experience of new product commercialisation, chi-square analysis confirms a significant relationship between independent inventors success and possessing previous experience of new product commercialisation $\chi^{2}(2, N=197)=13.02, P=.001$

Table 8: Independent inventor previous experience of new product commercialisation

\section{Insert table 8 here}

Given our findings we accept Hypothesis 4: Independent inventor success will be a significant and positive function of their previous experience of New Product Commercialisation

\section{Human capital resources - Judgement regarding the need for a return on investment}

Those inventors that have succeeded in achieving a licensing agreement are the most likely to attach importance to achieving a return on investment for their inventive efforts. In considering this independent variable a one-way analysis of variance was performed. Since the homogeneity of variances assumption was violated $(\mathrm{P}=.002)$ we used Welch's adjusted $\mathrm{F}$ ratio, which was significant at the alpha level of $.05(\mathrm{~F}(2,73.66)=4.74, \mathrm{P}=.01$ Post-hoc comparisons of the three groups using 
the Games-Howell procedure was conducted and revealed significant differences in the means of those inventors that had successfully licensed their technology and those that were not engaged with the process $(\mathrm{P}=.01)$.

We therefore accept Hypothesis 5: Independent inventor success will be a significant and positive function of a desire for a return on investment from inventive efforts.

Human capital resources - Inventor capacity to easily identify and gain access to potential licensees

Inventors, regardless of group, generally agree that identifying a potential licensee is not easy. In performing a one-way analysis of variance we find no significant differences in the means scores between the inventor groups under consideration $(F(2,185)=0.33, P=.72$

In terms of gaining access to potential licensees, successful Inventors are the least likely to believe that getting access to a potential licensee is difficult, however in performing a one-way analysis of variance we find no significant differences between the mean scores of the inventor groups under consideration $(\mathrm{F}(2,165)=1.65, \mathrm{P}=.20$

On the basis of the data presented, we reject Hypothesis 6: Independent inventor success will be a significant and positive function of their ability to identify and gain access to potential licensees

\section{Human capital resources - Inventor judgements concerning the characteristics of potential licensees}

In considering the "Must have the manufacturing capability to produce my innovation" variable, successful inventors are least inclined to feel this is an important characteristic. One-way ANOVA, relating to this independent variable, reveals a significant difference between the three inventor groupings $(\mathrm{F}(2,178)=3.47, \mathrm{P}=.03$ Post-hoc comparisons of the three groups using the Tukey HSD procedure was conducted and revealed differences in the means of those inventors that had successfully licensed their technology and those that were attempting to license, but as yet unsuccessfully $(\mathrm{P}=.03)$.

Successful inventors are the most inclined to believe that potential licensees should have an established brand in a market relevant to their invention. One-way analysis of variance on this variable yields a significant difference between the three groups $(\mathrm{F}(2,176)=3.77, \mathrm{P}=.03$ Post-hoc tests using Tukey HSD revealed differences in the means of successful inventors and those inventors not engaged in licensing $(\mathrm{P}=.02)$

We accept Hypothesis 7: Independent inventor success will be a significant and positive function of judgements concerning the characteristic of potential licensees. 


\section{Independent inventor capabilities \\ Capabilities - Membership of an inventor club}

Table 9: Independent inventor membership of an inventor club

Insert table 9 here

There is little difference in the level of inventor club membership across the three inventor groupings under consideration. Indeed, chi-square analysis reveals no evidence of a significant relationship between inventor success and inventor club membership $\chi^{2}(2, N=198)=1.24, P=.54$

We reject Hypothesis 8: Independent inventor success will be a positive and significant function of inventor club membership.

\section{Capabilities - Collaboration with knowledge-laden institutions}

Table 10: Extent of independent inventor collaboration with knowledge-laden institutions

Insert table 10 here

Chi Square analysis of the data relating to inventor collaboration with knowledge-laden institutions allows us to confirm a significant relationship between inventor success and collaboration with Universities $\chi^{2}(2, N=201)=11.59, P=.003$.

Interestingly we also find that no collaboration with knowledge-laden institutions hampers the prospects of independent inventors achieving a licensing agreement $\chi^{2}(2, N=201)=12.66, P=.002$

We found no evidence of a significant relationship between the dependent variable and other independent variables under consideration here.

We accept Hypothesis 9: Independent inventor success will be a positive and significant function of their collaboration with knowledge-laden institutions.

\section{Capabilities - Collaboration with external professionals}

Table 11: Extent of independent inventor collaboration with external professionals

\section{Insert table 11 here}

We find that the use of Patent Agents positively influences the inventors capacity to achieve a completed license agreement $\chi^{2}(2, N=201)=8.41, P=.02$, however no other significant relationships were found. 
On the basis of the significant relationship between inventor success and collaboration with Patent Agents we accept Hypothesis 10: Independent inventor success will be a positive and significant function of collaboration with external professionals.

Capabilities - Use of commercial and technical viability assessments

Chi-squared analysis confirms a positive and significant relationship between independent inventor success and the integration of commercial assessments within the new product introduction process $\chi^{2}(2, N=190)=11.39, P=.003$

Table 12: Independent inventor use of commercial assessment

Insert table 12 here

In a similar vein we consider independent inventor utilisation of technical assessments to validate the viability of their invention.

Table 13: Independent inventor use of technical viability assessment

Insert table 13 here

Pearson Chi-Square analysis reveals a significant relationship between inventor success and the use of technical assessments within the new product introduction process $\chi^{2}(2, N=194)=11.34, P=.003$

We accept Hypothesis 11: Independent inventor success will be a positive and significant function of utilising commercial and technical assessments as part of the new product introduction process. 


\section{Discussion}

The objectives of this research inquiry are two-fold, firstly to identify the key resource bundle possessed by successful independent inventors. Secondly, to suggest a preliminary screening tool that enables businesses involved in inbound open innovation to identify technology in-licensing opportunities from independent inventors.

This section of the paper is structured so as to provide discussion on each of these research objectives in turn.

Key resource bundle possessed by successful independent inventors

Resource-based theory suggests that independent inventors possess a bundle of resources and that these are the basis upon which an innovative advantage is secured. Key resources include:

\section{Access to a dedicated workshop and raw materials}

We find that independent inventors who achieve success, via a completed licensing agreement, are more likely than their less successful colleagues to have access to a dedicated workshop in which to conduct inventive activity, and be able to access raw materials. This finding is consistent with the view presented by Whalley (1991) in his article relating to the social practice of independent inventing. We found no statistically significant link however, between independent inventor success, via licensing, and having access to machinery and equipment to realise the innovation in a physical format, which is a departure from the views expressed by Whalley (1991).

\section{Holding formal qualifications in an aligned field}

While we found no statistically significant link between the level of formal qualifications held and independent inventor success, our data does suggest that independent inventors who invent in a field where they hold some form of qualification are more likely to succeed in licensing their technology. This reinforces the work of Lettl et al. (2009) who suggested that knowledge in a field is required in order to develop impactful technologies.

\section{Previous experience of new product commercialisation}

Independent inventors that have previous experience of new product commercialisation are more likely to achieve a completed license agreement with an organisation than counterparts not previously exposed to this process. This finding is consistent with organisational-level literature relating new product development where learning the lessons of previous attempts at commercialisation is integral to future success (Lynn et al., 1999)

\section{Seek a return of investment}


We find that independent inventors who succeed in achieving a completed licensing agreement are more likely to desire a return on investment for innovative efforts than their less successful colleagues. This mind-set is perhaps important since it demonstrates that inventor and organisational aspirations are at least broadly similar, while providing impetus for the inventor to seek a licensee.

Target brands established in the marketplace

Inventors that succeed in achieving a licensing deal are most likely to target potential licensees on the basis of them having an established brand in the market relevant to the innovation, rather than select potential licensees based on their manufacturing capability. Earlier work conducted by Mayer (2005) suggested that licensees should possess both access to the market and manufacturing capability, but we do not find a statistically significant link between inventors targeting licensees based on them having appropriate manufacturing facilities and licensing success.

Key routines

In addition to the above, the following routines are critical to inventors seeking success via a licensing agreement: working collaboratively with Universities as a means of gaining access to knowledge; utilising Patent Agents to deal with intellectual property issues and subjecting innovation(s) to commercial and technical viability assessments as part of the new product development process. In respect of collaboration with Universities and Patent Agents, our findings link in with systems of innovation literature whereby network linkages to institutions and individuals within the innovation system are seen as beneficial (Edquist, 1997)

\section{A sustainable innovative advantage?}

While the resource bundle identified previously yields an innovative advantage for the independent inventor, the extent to which this advantage is sustainable is debatable. We suggest that businesses operating inbound open innovation would benefit from attracting independent inventors that hold a sustainable innovative advantage, since the outputs would be consistently better. Barney (1991) suggests that the notion of sustainability is only achieved if the resources meet the VRIN criteria: Valuable, Rare, Inimitable and Non-Substitutable. An examination of the resource and capabilities bundle identified suggests that perhaps only previous experience of new product commercialisation meets the criteria, although we acknowledge that this view is open to criticisms of subjectivity.

\section{Preliminary Screening Tool}

Reasons for not integrating independent inventors into open innovation include a general lack of knowledge relating to this external source of knowledge, the sheer volume of enquiries received, which dilutes the businesses ability to identify and assimilate new knowledge (Kotabe et al., 2007) 
and the diverse nature of inventor approaches (Dahlin et al. 2004; Astebro, 2003). In considering the findings of our research we recommend that businesses seek to minimise the volume and variability problems (Smeilus et al., 2011b; Kotabe et al., 2007; Dahlin et al. 2004; Astebro, 2003) experienced when seeking technology in-licensing opportunities from independent inventors by implementing a preliminary screening tool based upon the resources commanded by the independent inventor.

The tool is essentially a question set that seeks to establish whether the independent inventor making the approach commands the resources required to develop a product/process that is likely to represent a reasonable in-licensing opportunity. A question-set similar to that presented in table 14 would be appropriate: 
Table 14: Preliminary Screening Tool for use by an organisations Core Team when assessing technology in-licensing opportunities from independent inventors

Insert table 14 here

An important factor in detailing this question-set is that the inventor is not required to disclose potentially confidential information relating to the product/process. As such this tool might be used regardless of the organisations stance on signing non-disclosure agreements in the absence of a formal patent application. The suggested tool also provides a "quick and dirty" method of filtering out high volumes of submissions of a diverse nature.

Question 8 of the preliminary screening tool allows the organisation operating inbound innovation to identify opportunities that reside within fields where they have the institutional knowledge to assimilate the new knowledge on offer; in line with absorptive capacity theory (Zahra and George, 2002)

\section{Conclusion}

This paper makes a number of important contributions to research and practice. Firstly, we provide a UK perspective on independent inventors, which satisfies a request for non-US studies into independent inventors made by Weick and Eakin (2005). Secondly, we believe that this is the first investigation into the resources independent inventors should command in order to succeed in agreeing a licensing deal with an organisation. Previous literature does not distinguish between commercialisation modes, so the specific requirements of the licensing route are not considered. Additionally, literature on achieving licensing success at an organisational-level is not directly applicable to the study of individuals, so this study provides a unique insight.

Our third contribution to research and practice is the development of a preliminary screening tool that we believe facilitates the identification of promising technology in-licensing opportunities emanating from independent inventors. The tool provides a number of practical advantages to businesses attempting to leverage knowledge from independent inventors. Initially, the short question-set allows a rapid assessment of whether the inventor possesses the resources to succeed in technology inlicensing. This facilitates a significant labour and administrative cost saving for organisations operating inbound open innovation, but also aids organisational absorptive capacity by reducing the amount of information under consideration at any one time and restricting approaches to fields where the organisation has some prior knowledge. The fact that the preliminary screening tool allows the shortlisting of inventor approaches without the need to hold a meeting or sign up to non-disclosure 
agreements is beneficial from a cost perspective, but is also useful for organisations where signing non-disclosure agreements is against organisational policy.

Finally, the paper also reinforces the development of resource-based theory by placing the resource as the unit of analysis; an approach advocated in the extant literature. We find that the resource-based theory is an effective foundation upon which to examine inventor success and the antecedents to innovative advantage.

\section{Limitations and Future Research}

This survey is based upon a non-probability sample of UK independent inventors and as such we acknowledge the existence of bias. The sampling frame largely excludes independent inventors that have chosen not to collaborate with an inventor support organisation and as such their views are likely to be under-represented.

Generating a large proportion of the sample through inventor support organisations also yields negative consequences in so much that results relating to the importance of collaborative action may be skewed to make collaboration with universities, for example, appear more significant to inventor success than is actually the case.

The use of snowball sampling is also a limitation of this research inquiry. While we maintain that this approach is the most appropriate given the difficulty in accessing what is essentially a "hidden population", we acknowledge that there is an extent to which control over who forms the sample is lost when employing this technique.

In denoting a "successful inventor" as one who has achieved a signed license agreement we leave ourselves open to criticism. In instances where the inventor has attempted to license many inventions, but succeeded just once an argument can be made that the inventor is not actually successful at all. Similarly, for inventors that are still in the process of licensing, it may ultimately be that the inventor succeeds, but it is merely too early to judge.

In terms of future research we would urge academics to offer insight into how, through the development of organisational processes, greater value can be leveraged from independent inventors as part of an inbound open innovation strategy. Inventors appear to be capable of offering radical innovations that are difficult to achieve with in-house $R \& D$ departments, yet we are still to establish guidance and organisational processes that illustrate how this source of external knowledge can be effectively leveraged. In addition, we know little about the issues that may arise in managing the relationship between the independent inventor and organisation following a signed licensing 
agreement or how effective inventors are in transferring their knowledge across to the licensee postcontract. Clearly, many questions still exist with regards to independent inventor engagement with open innovation, but as a research community we should begin to tackle them. 


\section{References}

Albaum, G. (1975) The Independent Inventor. Oregon: Eugene.

Alvarez, S. H. and Busenitz, L. W. (2001) The entrepreneurship of resource-based theory. Journal of Management, 27(1), p.20.

Anderson, H. (2004) Why big companies can't invent. Technology Review, 107(4), p.4.

Astebro (1998) Basic statistics on the success rate and profits for independent inventors Entrepreneurship Theory and Practice, 23(1), pp.41-48.

Astebro, T. (2003) The return to independent invention: Evidence of unrealistic optimism, risk seeking or skewness loving? The Economic Journal, 113(484), p.14.

Åstebro, T. and Michela, J. L. (2005) Predictors of the survival of innovators. The Journal of Product Innovation Management, 22(4), p.13.

Barney, J. B. (1986a) Strategic factor markets: Expectations, luck and business. Management Science, 32(1), p.3.

Barney, J. B. (1986b) Organizational culture: Can it be a source of sustained competitive advantage? Academy of Management Review, 11(1), p.10.

Barney, J. B. (1991) Firm Resources and Sustained Competitive Advantage. Journal of Management, 17(1), p.21.

Barney, J. B. (1997) Gaining and sustaining competitive advantage. Reading, MA.: AddisonWesley.

Barney, J. B. (2001) Is the Resource-Based "View" a Useful Perspective for Strategic Management Research? Yes. Academy of Management Review, 26(1), p.16.

Barney, J. B. and Mackey, T. B. (2005) Testing resource-based theory. in Ketchen, D. J. and Bergh, D. D. (eds.) Research methodology in strategy and management. Greenwich: Elsevier, pp.1-13.

Becker, G. S. (1964) Human Capital. New York: Columbia.

Bianchi, M., Cavaliere, A., Chiaroni, D., Frattini, F. and Chiesa, V. (2011) Organisational modes for open innovation in the bio-pharmaceutical industry: an exploratory analysis. Technovation, 31(1), p.12.

Bonner, J. M. and Walker, O. C. (2004) Selecting Influential Business-to-Business Customers in New Product Development: Relational Embeddedness and Knowledge Heterogeneity Considerations. Journal of Product Innovation Management, 21(3), p.15.

Bughin, J., Chui, M. and Johnson, B. (2008) The next step in open innovation. The McKinsey Quarterly, 4(6), p.8.

Chesbrough, H. (2003) Open Innovation: The new imperative for creating and profiting from technology. Boston, MA: Harvard Business School Publishing. 
Chesbrough, H. and Crowther, A. K. (2006) Beyond high tech: early adopters of open innovation in other industries. R\&D Management, 36(3), pp.229-236.

Chesbrough, H., Vanhaverbeke, W. and West, J. (2006b) Open Innovation: Researching a New Paradigm. Oxford: Oxford University Press.

Coe, N. M. and Bunnell, T. G. (2003) 'Spatializing'knowledge communities: towards a conceptualization of transnational innovation networks. Global Networks, 3(4), p.20.

Cohen, W. M. and Levinthal, D. A. (1990) Absorptive capacity: a new perspective on learning and innovation. Administrative science quarterly, 35(1), p.26.

Cooper, R. G. and Klienschmidt, E. J. (2007) Winning Business in New Product Development: The Critical Success Factors. Research-Technology Management, (May-June), p.16.

Dagenais, D. L., Seguin-Delude, L. and Desranleau, C. (1991) Analysis of individual Canadian inventor behaviour. Technovation, 11(6), pp.357-372.

Dahan, E. and Hauser, J. R. (2002) The virtual customer. Journal of Product Innovation Management, 19(5), p.22.

Dahlin, K., Taylor, M. and Fichman, M. (2004) Today's Edisons or weekend hobbyists: technical merit and success of inventions by independent inventors. Research Policy, 33(1), pp.11671183.

Dittrich, K., Dusters, G. and De Man, A. P. (2007) Strategic Repositioning by means of alliances networks: the case of IBM. Research Policy, 36(1), p.16.

Edquist, C. and Johnson, B. (1997). 'Institutions and organisations in systems of innovation', in C. Edquist (ed.) Systems of Innovation: Technologies, Institutions and Organizations.

London and Washington: Pinter/Cassell Academic.

Eisenhardt, K. M. and Martin, J. A. (2000) Dynamic capabilities: What are they? Strategic Management Journal, 21(1), p.16.

Enkel, E. and Gassmann, O. (2008) Driving open innovation in the front end. The IBM case. Working Paper University of St. Gallen and Zeppelin University, St. Gallen and Friedrichshafen.

Félix-Medina, M. H. and Monjardin, P. E. (2010) Combining link-tracing sampling and cluster sampling to estimate totals and means of hidden human populations. Journal of Official Statistics, 26(4), p.29.

Gassmann, O., Enkel, E. and Chesbrough, H. (2006) The future of open innovation. $R \& D$ Management, 40(3), p.9.

Henderson, R. and Cockburn, I. (1994) Measuring Competence?: Exploring firm effects in pharmaceutical research. Strategic Management Journal, 15((Special Issue)), p.21.

Huber, J. C. (1998) Invention and inventivity is a random, Poisson process: A potential guide to analysis of general creativity. Creativity Research Journal, 11(3), p.11. 
Hughes, T. P. (ed) (2004) American genesis: a century of invention and technological enthusiasm, 1870-1970. 2 ed., Chicago: University of Chicago Press, p. 513.

Jensen, R. A., Thursby, J. G. and Thursby, M. C. (2003) Disclosure and licensing of University inventions: 'The best we can do with the $\mathrm{s}^{* *} \mathrm{t}$ we get to work with'. International Journal of Industrial Organization, 21(9), p.30.

Kaufman, A., Wood, C. H. and Theyel, G. (2000) Collaboration and technology linkages: a strategic supplier typology. Strategic Management Journal, 21(6), p.15.

Kotabe, M., Dunlap-Hinkler, D., Parente, R. and Mishra, H. A. (2007) Determinants of crossnational knowledge transfer and its effect on firm innovation. Journal of International Business Studies, 38(1), p.23.

Lacetera, N., Cockburn, I. and Henderson, R. M. (2004) Do firms change capabilities by hiring new people? A study of the adoption of science-based drug discovery. in Baum, J. A. C. and Mcgahan, A. M. (eds.) Business strategy over the industry life-cycle: Advances in strategic management. Boston, MA: Elsevier, pp.133-159.

Lazzarotti, V. and Manzini, R. (2009) Different modes of open innovation: A theoretical framework and an empirical study. International Journal of Innovation Management, 13(4), p.22.

Lettl, C., Rost, K. and Von Wartberg, I. (2009) Why are some independent inventors 'heroes' and others 'hobbyists'? The moderating role of technological diversity and specialization. Research Policy, 38(2), pp.243-254.

Lilien, G. L., Morrison, P. D., Searls, K., Sonnack, M. and Von Hippel, E. (2002) Performance assessment of the lead user idea-generation process for new product development. Management science, 48(8), p.18.

Lynn, G. S., Abel, K. D., Valentine, W. S. and Wright, R. C. (1999) Key Factors in Increasing Speed to Market and Improving New Product Success Rates. Industrial Marketing Management, 28(1), pp.320-329.

Macdonald, S. (1986) The distinctive research of the individual inventor. Reserch Policy, 15(4), p.11.

Mahoney, J. T. and Pandain, J. (1992) The resource-based view within the conversation of strategic management. Strategic Management Journal, 13(5), p.17.

Mansfield, E., Rapoport, J., Romeo, A., Wagner, S. and Beardsley, G. (1977) Social and private rates of return from industrial innovations. The Quarterly Journal of Economics, 91(2), p.19.

Martinez, J. I. and Jarillo, J. C. (1989) The Evolution of Research on coordination mechanisms in multi-national corporations. Journal of International Business Studies, 20(3), p.26.

Mayer, M. (2005) Independent Inventors and public support measures:insights from 33 case studies in Finland. World Patent Information, 27(1), pp.113-123.

Mortara, L. and Minshall, T. (2011) How do large multinational companies implement open innovation? Technovation, 31(10), p.12. 
Nelson, R. R. and Winter, S. G. (1982) An evolutionary theory of economic change. Cambridge, MA.: Harvard University Press.

Olson, E. L. and Bakke, G. (2001) Implementing the lead user method in a high technology firm: A longitudinal study of intentions versus actions. Journal of product innovation management, 18(6), p.8.

Owen-Smith, J. and Powell, W. W. (2001) To patent or not: Faculty decisions and institutional success at technology transfer. The Journal of Technology Transfer, 26(1), p.16.

Parker, R. S., Udell, G. G. and Blades, L. (1996) The New Independent Inventor: Implications for Corporate Policy. Review of Business, 17(3), pp.7-11.

Perkmann, M. and Walsh, K. (2007) University-industry relationships and open innovation: Towards a research agenda. International Journal of Management Reviews, 9(4), p.22.

Peteraf, M. A. (1993) The cournerstones of competitive advantage: A resource-based view. Startegic Management Journal, 14(1), p.12.

Porter, M. and Stern, S. (2001) Innovation: Location Matters. MIT Sloan Management Review, Summer, pp.28-35.

Prusa, T. J. and Schmitz, J. A. (1991) Are new firms an important source of innovation? Evidence from the PC software industry. Economics Letters, 35(1), p.4.

Rothaermel, F. T. and Hess, A. M. (2007) Building Dynamic Capabilities: Innovation driven by individual-, firm-, and network-level effects. Organization Science, 18(6), p.23.

Schmookler, J. (1957) Inventors past and present. The Review of Economics and Statistics, 39(3), p.13.

Schrage, M. (2003) Amateur Innovation. Technology Review, June.

Schumpeter, J. (1939) Theoretical, historical and statistical analysis of the capitalist process. New York: McGraw-Hill.

Schumpeter, J. A. (1934) The theory of economic development. Cambridge, MA: Harvard Economic Studies.

Schumpeter, J. A. (1942) Capitalism, Socialism and Democracy. New York: Harper.

Singh, J., Marx, M. and Fleming, L. (2010) Patent Citations and the Geography of Knowledge Spillovers: Disentangling the Role of State Borders, Metropolitan Boundaries and Distance. Fontainebleau, France: Insead

Sirilli, G. (1987) Patents and Inventors: An empirical study. Research Policy, 16(1), pp.157-169.

Smeilus, G. E., Harris, R. J. and Pollard, A. (2011a) An Examination of Independent Inventor Integration in Open Innovation. in Nobre, F., Walker, D. and Harris, R. J. (eds.) Technological, Managerial and Organizational Core Competencies: Dynamic Innovation and Sustainable Development. 1 ed.: IGI Global, pp.146-166. 
Smeilus, G. E., Harris, R. J. and Pollard, A. (2011b) The integration of independent inventors in open innovation. in Nobre, F., Walker, D. and Harris, R. J. (eds.) Technological, Managerial and Organizational Core Competencies: Dynamic Innovation and Sustainable advantage. 1 ed.: IGI Global, pp.131-145.

Sobrero, M. and Roberts, E. B. (2002) Strategic management of supplier-manufacturer relations in new product development. Research Policy, 31(1), p.23.

Spithoven, A., Clarysse, B. and Knockaert, M. (2011) Building absorptive capacity to organise inbound open innovation in traditional industries. Technovation, 31(1), p.12.

Teece, D., Pisano, G. and Shuen, A. (1997) Dynamic capabilities and strategic management. Strategic Management Journal, 18(1), p.24.

Thursby, J. G. and Kemp, S. (2002) Growth and productive efficiency of university intellectual property licensing. Research Policy, 31(1), p.16.

Von Hippel, E. and Katz, R. (2002) Shifting innovation to users via toolkits. Management science, 48(7), p.13.

Weick, C. W. and Eakin, C. F. (2005) Independent inventors and innovation: an empirical study. International Journal of Entrepreneurship and Innovation, 6(1), pp.5-15.

Weick, C. W. and Martin, J. D. (2006) Full-time and part-time independent inventors: Rising with the creative class. Entrepreneurship and Innovation, 7(1), pp.5-12.

Whalley, P. (1991) The social practice of independent inventing. Science, Technology and Human Values, 16(2), pp.232-256.

Williamson, O. E. (1975) Markets and hierarchies: Analysis and antitrust implications. New York: Free Press.

Winter, S. G. (1995) The four R's of profitability: rents, resources, routines and replication. in Montgomery, C. A. (ed.) Resource-based and evolutionary theories of the firm. Boston, MA: Kluwer, pp.147-178.

Zahra, S. A. and George, G. (2002) Absorptive capacity: A review, reconceptualization, and extension. Academy of management review, 27(2), p.19. 
Table 1:

\begin{tabular}{|c|c|c|}
\hline Physical Capital Resources & Human Capital Resources & Routines \\
\hline $\begin{array}{l}\text { - Access to inventive space } \\
\text { - Access to raw materials } \\
\text { - Access to appropriate } \\
\text { machinery \& equipment } \\
\text { - Ability to self-finance the } \\
\text { development programme }\end{array}$ & $\begin{array}{l}\text { - Level of formal } \\
\text { qualifications } \\
\text { - Formal qualifications in the } \\
\text { field in which invention } \\
\text { occurs } \\
\text { - } \quad \text { Previous experience of new } \\
\text { product commercialisation } \\
\text { - Judgement regarding the } \\
\text { characteristics of potential } \\
\text { licensees: ease of } \\
\text { identification and access } \\
\text { - Judgements over the } \\
\text { financial rewards inventors } \\
\text { should receive via a license }\end{array}$ & 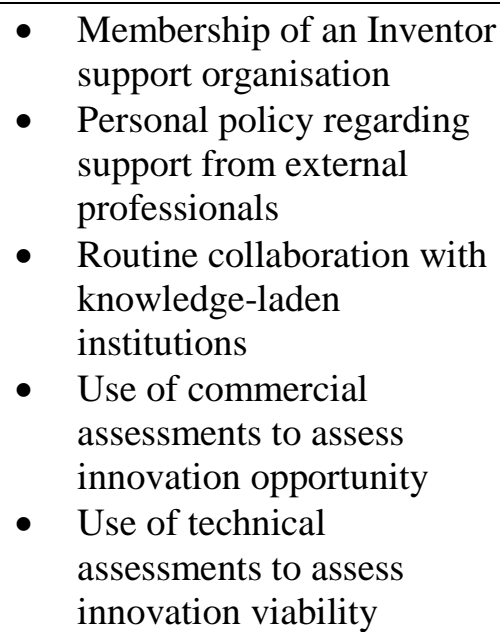 \\
\hline
\end{tabular}

Table 2:

\begin{tabular}{|l|c|c|c|c|c|c|}
\hline & \multicolumn{2}{|c|}{$\begin{array}{c}\text { Inventor has } \\
\text { successfully licensed } \\
\text { technology }\end{array}$} & $\begin{array}{c}\text { Inventors attempting to } \\
\text { license their } \\
\text { technology, but as yet } \\
\text { unsuccessful }\end{array}$ & $\begin{array}{c}\text { Inventors having no } \\
\text { engagement with the } \\
\text { licensing process to } \\
\text { date }\end{array}$ \\
\hline & Count & $\begin{array}{c}\text { Column } \\
\%\end{array}$ & Count & $\begin{array}{c}\text { Column } \\
\%\end{array}$ & Count & $\begin{array}{c}\text { Column } \\
\%\end{array}$ \\
\hline Inventor Success & 24 & $11.4 \%$ & 56 & $27.7 \%$ & 122 & $60.4 \%$ \\
\hline & & & & & & \\
\hline
\end{tabular}


Table 3:

\begin{tabular}{|l|c|c|c|c|c|c|}
\hline & \multicolumn{2}{|c|}{$\begin{array}{c}\text { Inventor has } \\
\text { successfully licensed } \\
\text { technology }\end{array}$} & $\begin{array}{c}\text { Inventors attempting to } \\
\text { license their } \\
\text { technology, but as yet } \\
\text { unsuccessful }\end{array}$ & $\begin{array}{c}\text { Inventors having no } \\
\text { engagement with the } \\
\text { licensing process to } \\
\text { date }\end{array}$ \\
\hline & Count & $\begin{array}{c}\text { Column } \\
\%\end{array}$ & $\begin{array}{c}\text { Count } \\
\text { Column }\end{array}$ & $\begin{array}{c}\text { Count } \\
\text { Column } \\
\%\end{array}$ \\
\hline Sex: & 23 & $95.8 \%$ & 45 & $80.4 \%$ & 98 & $81.7 \%$ \\
\hline Male & 1 & $4.2 \%$ & 11 & $19.6 \%$ & 22 & $18.3 \%$ \\
\hline Female & & & & & & \\
\hline & & & & & & \\
\hline Age: & 3 & $12.5 \%$ & 8 & $14.3 \%$ & 27 & $22.7 \%$ \\
\hline 40 -years or younger & 6 & $25.0 \%$ & 23 & $41.1 \%$ & 29 & $24.4 \%$ \\
\hline $41-50$ years & 6 & $25.0 \%$ & 14 & $25.0 \%$ & 31 & $26.1 \%$ \\
\hline $51-60$ years & 9 & $37.5 \%$ & 11 & $19.6 \%$ & 32 & $26.9 \%$ \\
\hline 61 years or older & & & & & & \\
\hline & & & & & & \\
\hline Employment status: & 18 & $78.3 \%$ & 30 & $60.0 \%$ & 69 & $67.0 \%$ \\
\hline Employed & 2 & $8.7 \%$ & 11 & $22.0 \%$ & 15 & $14.6 \%$ \\
\hline Not Employed & 3 & $13.0 \%$ & 9 & $18.0 \%$ & 19 & $18.4 \%$ \\
\hline Retired & & & & & & \\
\hline
\end{tabular}

Table 4:

\begin{tabular}{|l|c|c|c|c|c|c|}
\hline & \multicolumn{2}{|c|}{$\begin{array}{c}\text { Inventor has } \\
\text { successfully licensed } \\
\text { technology }\end{array}$} & $\begin{array}{c}\text { Inventors attempting to } \\
\text { license their } \\
\text { technology, but as yet } \\
\text { unsuccessful }\end{array}$ & $\begin{array}{c}\text { Inventors having no } \\
\text { engagement with the } \\
\text { licensing process to } \\
\text { date }\end{array}$ \\
\hline & Count & $\begin{array}{c}\text { Column } \\
\%\end{array}$ & Count & $\begin{array}{c}\text { Column } \\
\%\end{array}$ & Count & $\begin{array}{c}\text { Column } \\
\%\end{array}$ \\
\hline Fully self-finance & 8 & $38.1 \%$ & 12 & $24.5 \%$ & 29 & $26.6 \%$ \\
\hline Partially self-finance & 8 & $38.1 \%$ & 18 & $36.7 \%$ & 47 & $43.1 \%$ \\
\hline Unable to self-finance & 5 & $23.8 \%$ & 19 & $38.8 \%$ & 33 & $30.3 \%$ \\
\hline & & & & & & \\
\hline
\end{tabular}


Table 5:

\begin{tabular}{|l|c|c|c|c|c|c|}
\hline & \multicolumn{2}{|c|}{$\begin{array}{c}\text { Inventor has } \\
\text { successfully licensed } \\
\text { technology }\end{array}$} & $\begin{array}{c}\text { Inventors attempting to } \\
\text { license their } \\
\text { technology, but as yet } \\
\text { unsuccessful }\end{array}$ & $\begin{array}{c}\text { Inventors having no } \\
\text { engagement with the } \\
\text { licensing process to } \\
\text { date }\end{array}$ \\
\hline & Count & $\begin{array}{c}\text { Column } \\
\%\end{array}$ & $\begin{array}{c}\text { Count } \\
\text { Column } \\
\%\end{array}$ & $\begin{array}{c}\text { Count } \\
\text { Column } \\
\%\end{array}$ \\
\hline Own Garage / Home & 10 & $41.7 \%$ & 32 & $58.2 \%$ & 58 & $47.5 \%$ \\
\hline Dedicated Workshop & 11 & $45.8 \%$ & 11 & $20.0 \%$ & 26 & $21.3 \%$ \\
\hline Laboratory & 2 & $8.3 \%$ & 4 & $7.3 \%$ & 4 & $3.3 \%$ \\
\hline Third-Party Space & 2 & $8.3 \%$ & 7 & $12.7 \%$ & 11 & $9.0 \%$ \\
\hline $\begin{array}{l}\text { Nowhere to Develop } \\
\text { Prototype }\end{array}$ & 1 & $4.2 \%$ & 9 & $7.7 \%$ & 18 & $14.8 \%$ \\
\hline
\end{tabular}

Table 6:

\begin{tabular}{|l|c|c|c|c|c|c|}
\hline & \multicolumn{2}{|c|}{$\begin{array}{c}\text { Inventor has } \\
\text { successfully licensed } \\
\text { technology }\end{array}$} & $\begin{array}{c}\text { Inventors attempting to } \\
\text { license their } \\
\text { technology, but as yet } \\
\text { unsuccessful }\end{array}$ & $\begin{array}{c}\text { Inventors having no } \\
\text { engagement with the } \\
\text { licensing process to } \\
\text { date }\end{array}$ \\
\hline & Count & $\begin{array}{c}\text { Column } \\
\%\end{array}$ & $\begin{array}{c}\text { Count } \\
\text { Column } \\
\%\end{array}$ & Count & $\begin{array}{c}\text { Column } \\
\%\end{array}$ \\
\hline Graduate or above & 10 & $45.5 \%$ & 32 & $59.3 \%$ & 47 & $42.7 \%$ \\
\hline Below graduate & 12 & $54.5 \%$ & 22 & $40.7 \%$ & 63 & $57.3 \%$ \\
\hline & & & & & & \\
\hline
\end{tabular}

Table 7:

\begin{tabular}{|l|c|c|c|c|c|c|}
\hline & \multicolumn{2}{|c|}{$\begin{array}{c}\text { Inventor has } \\
\text { successfully licensed } \\
\text { technology }\end{array}$} & $\begin{array}{c}\text { Inventors attempting to } \\
\text { license their } \\
\text { technology, but as yet } \\
\text { unsuccessful }\end{array}$ & \multicolumn{2}{|c|}{$\begin{array}{c}\text { Inventors having no } \\
\text { engagement with the } \\
\text { licensing process to } \\
\text { date }\end{array}$} \\
\hline & Count & $\begin{array}{c}\text { Column } \\
\%\end{array}$ & Count & $\begin{array}{c}\text { Column } \\
\%\end{array}$ & Count & $\begin{array}{c}\text { Column } \\
\%\end{array}$ \\
\hline $\begin{array}{l}\text { Hold formal } \\
\text { qualification in area of } \\
\text { invention }\end{array}$ & 11 & $47.8 \%$ & 25 & $45.5 \%$ & 32 & $27.4 \%$ \\
\hline $\begin{array}{l}\text { Do not hold formal } \\
\text { qualification in area of } \\
\text { invention }\end{array}$ & 12 & $52.2 \%$ & 30 & $54.5 \%$ & 85 & $72.6 \%$ \\
\hline
\end{tabular}


Table 8:

\begin{tabular}{|l|c|c|c|c|c|c|}
\hline & \multicolumn{2}{|c|}{$\begin{array}{c}\text { Inventor has } \\
\text { successfully licensed } \\
\text { technology }\end{array}$} & $\begin{array}{c}\text { Inventors attempting to } \\
\text { license their } \\
\text { technology, but as yet } \\
\text { unsuccessful }\end{array}$ & \multicolumn{2}{|c|}{$\begin{array}{c}\text { Inventors having no } \\
\text { engagement with the } \\
\text { licensing process to } \\
\text { date }\end{array}$} \\
\hline & Count & $\begin{array}{c}\text { Column } \\
\%\end{array}$ & Count & $\begin{array}{c}\text { Column } \\
\%\end{array}$ & Count & $\begin{array}{c}\text { Column } \\
\%\end{array}$ \\
\hline $\begin{array}{l}\text { Has previous NPI } \\
\text { experience }\end{array}$ & 18 & $75.0 \%$ & 20 & $37.7 \%$ & 43 & $35.8 \%$ \\
\hline $\begin{array}{l}\text { No previous NPI } \\
\text { experience }\end{array}$ & 6 & $25.0 \%$ & 33 & $62.3 \%$ & 77 & $64.2 \%$ \\
\hline & & & & & & \\
\hline
\end{tabular}

Table 9:

\begin{tabular}{|l|c|c|c|c|c|c|}
\hline & \multicolumn{2}{|c|}{$\begin{array}{c}\text { Inventor has } \\
\text { successfully licensed } \\
\text { technology }\end{array}$} & $\begin{array}{c}\text { Inventors attempting to } \\
\text { license their } \\
\text { technology, but as yet } \\
\text { unsuccessful }\end{array}$ & \multicolumn{2}{|c|}{$\begin{array}{c}\text { Inventors having no } \\
\text { engagement with the } \\
\text { licensing process to } \\
\text { date }\end{array}$} \\
\hline & Count & $\begin{array}{c}\text { Column } \\
\%\end{array}$ & Count & $\begin{array}{c}\text { Column } \\
\%\end{array}$ & Count & $\begin{array}{c}\text { Column } \\
\%\end{array}$ \\
\hline $\begin{array}{l}\text { Member of inventor } \\
\text { club }\end{array}$ & 10 & $41.7 \%$ & 26 & $48.1 \%$ & 47 & $39.2 \%$ \\
\hline $\begin{array}{l}\text { No inventor club } \\
\text { membership }\end{array}$ & 14 & $58.3 \%$ & 28 & $51.9 \%$ & 73 & $60.8 \%$ \\
\hline & & & & & & \\
\hline
\end{tabular}

Table 10:

\begin{tabular}{|l|c|c|c|c|c|c|}
\hline & \multicolumn{2}{|c|}{$\begin{array}{c}\text { Inventor has } \\
\text { successfully licensed } \\
\text { technology }\end{array}$} & $\begin{array}{c}\text { Inventors attempting to } \\
\text { license their } \\
\text { technology, but as yet } \\
\text { unsuccessful }\end{array}$ & $\begin{array}{c}\text { Inventors having no } \\
\text { engagement with the } \\
\text { licensing process to } \\
\text { date }\end{array}$ \\
\hline & Count & $\begin{array}{c}\text { Column } \\
\%\end{array}$ & Count & $\begin{array}{c}\text { Column } \\
\%\end{array}$ & Count & $\begin{array}{c}\text { Column } \\
\%\end{array}$ \\
\hline Universities & 14 & $58.3 \%$ & 27 & $49.1 \%$ & 35 & $28.7 \%$ \\
\hline Research Institutes & 3 & $12.5 \%$ & 6 & $10.9 \%$ & 8 & $6.6 \%$ \\
\hline $\begin{array}{l}\text { Government } \\
\text { Departments }\end{array}$ & 3 & $12.5 \%$ & 7 & $12.7 \%$ & 14 & $11.5 \%$ \\
\hline Public Funded Bodies & 1 & $4.2 \%$ & 8 & $14 . \%$ & 12 & $9.8 \%$ \\
\hline No Collaboration & 7 & $29.2 \%$ & 15 & $27.3 \%$ & 65 & $53.3 \%$ \\
\hline
\end{tabular}


Table 11:

\begin{tabular}{|c|c|c|c|c|c|c|}
\hline & \multicolumn{2}{|c|}{$\begin{array}{c}\text { Inventor has } \\
\text { successfully licensed } \\
\text { technology }\end{array}$} & $\begin{array}{c}\text { Inventor is engaged } \\
\text { with the licensing } \\
\text { process, but yet to } \\
\text { achieve success }\end{array}$ & $\begin{array}{c}\text { Inventor not engaged } \\
\text { in licensing process }\end{array}$ \\
\hline & Count & $\begin{array}{c}\text { Column } \\
\%\end{array}$ & Count & $\begin{array}{c}\text { Column } \\
\%\end{array}$ & Count & $\begin{array}{c}\text { Column } \\
\%\end{array}$ \\
\hline Patent Agent & 18 & $75.0 \%$ & 39 & $65.5 \%$ & 59 & $48.4 \%$ \\
\hline Market Researcher & 6 & $25.0 \%$ & 13 & $23.6 \%$ & 29 & $23.8 \%$ \\
\hline Solicitor & 8 & $33.3 \%$ & 15 & $27.3 \%$ & 26 & $21.3 \%$ \\
\hline Product Designer & 4 & $16.7 \%$ & 14 & $25.5 \%$ & 28 & $23.0 \%$ \\
\hline $\begin{array}{c}\text { No plans to use } \\
\text { professionals }\end{array}$ & 3 & $12.5 \%$ & 3 & $5.5 \%$ & 14 & $11.5 \%$ \\
\hline
\end{tabular}

Table 12:

\begin{tabular}{|l|c|c|c|c|c|c|}
\hline & \multicolumn{2}{|c|}{$\begin{array}{c}\text { Inventor has } \\
\text { successfully licensed } \\
\text { technology }\end{array}$} & $\begin{array}{c}\text { Inventors attempting to } \\
\text { license their } \\
\text { technology, but as yet } \\
\text { unsuccessful }\end{array}$ & \multicolumn{2}{|c|}{$\begin{array}{c}\text { Inventors having no } \\
\text { engagement with the } \\
\text { licensing process to } \\
\text { date }\end{array}$} \\
\hline & Count & $\begin{array}{c}\text { Column } \\
\%\end{array}$ & Count & $\begin{array}{c}\text { Column } \\
\%\end{array}$ & Count & $\begin{array}{c}\text { Column } \\
\%\end{array}$ \\
\hline $\begin{array}{l}\text { Perform commercial } \\
\text { assessment }\end{array}$ & 18 & $75.0 \%$ & 35 & $68.6 \%$ & 53 & $46.1 \%$ \\
\hline $\begin{array}{l}\text { No commercial } \\
\text { assessment undertaken }\end{array}$ & 6 & $25.0 \%$ & 16 & $31.4 \%$ & 62 & $53.9 \%$ \\
\hline & & & & & & \\
\hline
\end{tabular}

Table 13:

\begin{tabular}{|l|c|c|c|c|c|c|}
\hline & \multicolumn{2}{|c|}{$\begin{array}{c}\text { Inventor has } \\
\text { successfully licensed } \\
\text { technology }\end{array}$} & $\begin{array}{c}\text { Inventors attempting to } \\
\text { license their } \\
\text { technology, but as yet } \\
\text { unsuccessful }\end{array}$ & $\begin{array}{c}\text { Inventors having no } \\
\text { engagement with the } \\
\text { licensing process to } \\
\text { date }\end{array}$ \\
\hline & Count & $\begin{array}{c}\text { Column } \\
\%\end{array}$ & Count & $\begin{array}{c}\text { Column } \\
\%\end{array}$ & Count & $\begin{array}{c}\text { Column } \\
\%\end{array}$ \\
\hline $\begin{array}{l}\text { Perform technical } \\
\text { assessment }\end{array}$ & 17 & $70.8 \%$ & 39 & $72.2 \%$ & 55 & $47.4 \%$ \\
\hline $\begin{array}{l}\text { No technical } \\
\text { assessment undertaken }\end{array}$ & 7 & $29.2 \%$ & 15 & $27.8 \%$ & 61 & $52.6 \%$ \\
\hline & & & & & & \\
\hline
\end{tabular}


Table 14:

1. Do you possess formal qualifications in a technical field aligned with the invention under development? Please detail your qualifications and how they relate to your innovation.

2. Do you have previous experience of new product commercialisation? If so, please detail your experience

3. Do you have prototypes of your innovation that we can examine?

4. Have you collaborated with a university as part of the development process? What was the nature of this collaboration?

5. Is your innovation patented? If so, did you draft the patent application yourself or use a patent agent?

6. Have you had your innovation subjected to a technical and commercial viability assessment? Who undertook the assessment(s) and what was the outcome?

7. Why have you approached our organisation:

a. Because we have the manufacturing capability to produce your innovation

b. Because your innovation has a good synergy with our brand and the market(s) we operate in

8. Does your innovation fit within one of the following areas that our organisation is involved with:
a. Technology a / Sector a
b. Technology b / Sector b 